\title{
Primary production potential of non-geniculate coralline algae at Cape Evans, Ross Sea, Antarctica
}

\author{
Anne-Maree Schwarz ${ }^{1,3, *}$, Ian Hawes ${ }^{1,3}$, Neil Andrew ${ }^{2,4}$, Steve Mercer ${ }^{2}$, \\ Vonda Cummings ${ }^{2}$, Simon Thrush ${ }^{1}$
}

\author{
${ }^{1}$ National Institute of Water and Atmospheric Research, PO Box 11-115, Hamilton, New Zealand \\ ${ }^{2}$ National Institute of Water and Atmospheric Research, PO Box 14-901, Wellington, New Zealand \\ ${ }^{3}$ Present address: The Worldfish Center, PO Box 77, Gizo, Solomon Islands \\ ${ }^{4}$ Present address: The Worldfish Center, PO Box 500 GPO 10670, Penang, Malaysia
}

\begin{abstract}
The abundance and photosynthetic characteristics of non-geniculate coralline algae were determined at Cape Evans, McMurdo Sound (Ross Sea), Antarctica, during spring 2003. At the time, the site was covered by $2.5 \mathrm{~m}$ of sea-ice through which only $0.48 \%$ of incident irradiance was able to penetrate. Coralline algae covered 4 to $60 \%$ of the seafloor from water depths of 13 to $26 \mathrm{~m}$. Coralline algal crusts showed light-saturated rates of photosynthesis from 9.4 to $20 \mathrm{mmol} \mathrm{O}_{2} \mathrm{~m}^{-2}$ thallus $\mathrm{d}^{-1}$ and dark respiration rates from 0.15 to $0.96 \mathrm{mmol} \mathrm{O}_{2} \mathrm{~m}^{-2}$ thallus $\mathrm{d}^{-1}$. The average irradiance at which the onset of light saturated photosynthesis occurred $\left(E_{\mathrm{k}}\right)$ was $3.2 \mu \mathrm{mol}$ photons $\mathrm{m}^{-2} \mathrm{~s}^{-1}$, measured using oxygen micro-electrodes, and $2.9 \mu \mathrm{mol}$ photons $\mathrm{m}^{-2} \mathrm{~s}^{-1}$, measured using pulse amplitude modulated (PAM) fluorometry techniques. Irradiance at depths of 15 to $20 \mathrm{~m}$ did not exceed $2 \mu \mathrm{mol}$ photons $\mathrm{m}^{-2} \mathrm{~s}^{-1}$ during the study, but frequently exceeded the light compensation point for photosynthesis $\left(E_{\mathrm{c}}\right)$, estimated as $0.10 \mu \mathrm{mol}$ photons $\mathrm{m}^{-2} \mathrm{~s}^{-1}$. The effective quantum yield $\left(\Delta F / F_{\mathrm{m}}{ }^{\prime}\right)$ of Photosystem II, measured in situ over diel periods at depths of 16, 18 and $20 \mathrm{~m}$, averaged 0.691 (SD = $0.003), 0.639(\mathrm{SD}=0.005)$ and $0.632(\mathrm{SD}=0.007)$, respectively. These values were indicative of minimal down-regulation of photosynthesis, and were consistent with the observation that irradiance never exceeded $E_{\mathrm{k}}$. Laboratory investigations, showed that on transfer from ambient irradiance to $23.5 \mu \mathrm{mol}$ photons $\mathrm{m}^{-2} \mathrm{~s}^{-1}$, a change of 2 orders of magnitude, the algae showed minimal photoinhibition and a small, but statistically significant increase in $E_{\mathrm{k}}$ and maximum electron transport rate. Coralline algae at Cape Evans are able to persist with net carbon accrual under ice, while being able to tolerate periods of higher irradiance during ice-free conditions. This contrasts to Phyllophora antarctica which is dependent on ice-free periods to achieve net production.
\end{abstract}

KEY WORDS: Photosynthesis - Oxygen electrodes - Macroalgae - Phyllophora antarctica · Photoacclimation · Mesophyllum engelhartii $\cdot$ Synarthrophyton patena

Resale or republication not permitted without written consent of the publisher

\section{INTRODUCTION}

Non-geniculate or crustose, coralline algae occupy habitats that cover a broad range of irradiance. Some species occur in the extreme high irradiance of shallow tropical reefs (Payri et al. 2001), while other species comprise the deepest known record for attached macroalgae, where they receive less than $0.0009 \%$ of surface irradiance (Littler et al. 1991). The ability of coralline algae to grow in deep water has been associ- ated with a high photosynthetic efficiency and a high capacity to store photosynthate (Steneck 1986). Similar considerations are likely to apply to the ability of crustose corallines to dominate the flora of high-latitude marine systems where sea-ice plays a major role in structuring the light climate. Non-geniculate coralline algae have been described as being widespread in the Ross Sea (Zaneveld \& Sanford 1980), and are the dominant macroalgae at depths below those where it is possible for branched and foliose forms to grow (Cor- 
maci et al. 1998). Conspicuous coralline crusts are found at Cape Evans (Miller \& Pearse 1991) on Ross Island, Antarctica, and extend further south to Hut Point (Dayton 1990). Although previously referred to as Phymatolithon foecundum (Kjellman) Düwel et Wegeberg 1996 (Alongi et al. 2002), collections made during recent years in the Ross Sea suggest that the taxonomy of coralline algae in the region is, as yet, poorly defined. Samples collected from Cape Evans, the site for this study, have recently been identified as either Mesophyllum engelhartii (Foslie) Adey or Synarthrophyton patena (Hook.f. et Harv.) Townsend (A. Harvey pers. comm.). M. engelhartii and $S$. patena possess morphologically similar tetrasporangial conceptacles (Woelkerling 1996) and can only be separated by observing spermatangial filament branching in the male conceptacles (unbranched in $M$. engelhartii, but both branched and unbranched in S. patena). To date, distinguishing between these 2 species in samples from Cape Evans has not been possible as male conceptacles were not available in the samples.

Polar macroalgae in general (Kirst \& Wiencke 1995), including coralline algae in the high Arctic (Roberts et al. 2002), are well adapted to low light conditions. Nevertheless some polar macroalgae have also been shown to be capable of withstanding excessive light (Hanelt et al. 1997). An ability to acclimate to different light conditions is illustrated by some Antarctic taxa, including the foliose red algae Palmaria decipiens, by seasonal differences in photosynthetic performance that have been interpreted as enabling the algae to use short periods of relatively high irradiance soon after sea ice break-up (Kirst \& Wiencke 1995). While photoacclimation may include changes in the size of photosynthetic units, pigment composition, enzyme activity and/or the characteristics of P-I relationships (Kirst \& Wiencke 1995), the physiological adaptations that enable coralline algae to persist at great depths and high latitudes in the Antarctic, both of which impose strict limitations of the availability of light, remain poorly understood.

At Cape Evans, the branched red alga Phyllophora antarctica and coralline algae have overlapping depth distributions, with $P$. antarctica attached to rocks, occurring predominantly between 10 and $18 \mathrm{~m}$, while coralline algae extend from 10 to $>30 \mathrm{~m}$ (maximum diving depth) (Miller \& Pearse 1991, Schwarz et al. 2003). Previously, we have shown that irradiance consistently exceeds compensation levels for photosynthesis of $P$. antarctica, thereby enabling net carbon accumulation only during the ice-free period (ca. 2 mo in 2000-2001) (Schwarz et al. 2003). Given that corallines are found at much greater depths, we hypothesised that they would have a more efficient utilisation of available light than $P$. antarctica, achieved either through better assimilation of low light or through an enhanced ability to take up and store carbon during the periodic intervals of high light.

In this study, we quantify depth-dependent cover and pigment concentrations at 2 depths for coralline algae at Cape Evans. We present the results of oxygen exchange and pulse amplitude modulated (PAM) fluorometry investigations of the photosynthetic characteristics of under-ice material collected in spring 2003, and of experiments designed to assess their potential to respond to higher irradiance likely to be associated with summer ice-free conditions.

\section{MATERIALS AND METHODS}

Site description. This study was carried out at Cape Evans, Ross Island, Antarctica, between 29 October and 4 November 2003. Collections were made by SCUBA divers operating through an ice hole. The hole was located at $77^{\circ} 38.085^{\prime} \mathrm{S}, 166^{\circ} 24.843^{\prime} \mathrm{E}$ over a water depth of $20 \mathrm{~m}$, enabling SCUBA access to a depth range from 13 to $26 \mathrm{~m}$. A hut erected over the hole protected plant material that was collected from under the ice from temperature and light shock upon arrival at the surface.

Irradiance. Surface and under-ice photosynthetically available radiation (PAR) was measured using LiCor quantum sensors (Li190SA for surface and Li192SB for underwater irradiance). Irradiance measured by both sensors was logged at 5 min intervals using a Li-1000 data logger for $7 \mathrm{~d}$. The under-ice sensor was attached to the underside of the ice using an ice screw at a distance of $20 \mathrm{~m}$ from the dive hole. This distance was found to be adequate to avoid the effect of light focusing through the hole. The percent transmission through the ice was calculated for the logging period. On 2 occasions, divers made in situ measurements of irradiance using an Li192SB underwater sensor attached to a Li145 meter in a waterproof housing. Measurements were made at 4 depth intervals between 0 and $20 \mathrm{~m}$ below the ice, enabling the attenuation coefficient for downwelling irradiance $\left(K_{\mathrm{d}}\right)$ to be estimated from the slope of the log-transformed PAR values with depth (Kirk 1994).

Distribution and percent cover. A $50 \mathrm{~m}$ transect line was laid on the seafloor between water depths of 13 and $26 \mathrm{~m}$. The seafloor along the transect was videoed using a diver-held digital video camera at a fixed height of $70 \mathrm{~cm}$ above the bottom. The gradient of the transect was used to identify distances corresponding to $1 \mathrm{~m}$ depth increments, and at each of these a still image was captured from the video record using a Sony digital cassette recorder. The percent cover of 
coralline algae was estimated within an area of $0.5 \times$ $0.5 \mathrm{~m}$ in each captured frame, overlain by a grid equivalent to 636 squares, each $1 \times 1 \mathrm{~cm}$. The number of grid intercepts that coincided with coralline algae and/or rock substrate was counted. Percent cover was determined firstly as the proportion of total intercepts coinciding with coralline algae (total 2-dimensional cover) and secondly as the proportion of rock substrate occupied by coralline algae.

To supplement the video transect, 11 quadrats $(0.25 \times 0.25 \mathrm{~m})$ were photographed on a parallel transect (30 $\mathrm{m}$ away) using a digital camera in an underwater housing at depths of 15, 20 and $25 \mathrm{~m}$. The percent cover of corallines was analysed in the same way as described above.

Photosynthetic characteristics. In situ measurements: On 3 occasions, the fluorescence characteristics of Photosystem II (PS II) in coralline algae were measured under ambient irradiance in situ. A diveroperated, submersible Diving-PAM fluorometer (Walz) was positioned on the seafloor at depths of 16, 18 and $20 \mathrm{~m}$, respectively. The sensing fibre of the DivingPAM was clamped in such a way that it was held in a stationary position at a distance of $1 \mathrm{~cm}$ from the surface of the coralline crust. The Diving-PAM was programmed to take 1 measurement of the effective quantum yield of PS II $\left(\Delta F / F_{\mathrm{m}}{ }^{\prime}\right.$, Krause \& Weiss 1991) every 20 min. Measurements were made for up to $16 \mathrm{~h}$, depending on battery life, which was restricted at the ambient temperature of $-1.9^{\circ} \mathrm{C}$. The Diving-PAM was equipped with a red LED and settings were the same for each deployment.

Laboratory measurements: Small rocks (approximately $20 \mathrm{~cm}$ diameter) with a cover of coralline algae were collected from depths of 15 and $20 \mathrm{~m}$, chosen to represent depths with contrasting percent cover. Rocks were collected in darkened containers, brought to the surface and immediately transferred into dark, insulated containers within the dive hut. Experiments were conducted in the on-site laboratory to investigate acclimation to various light intensities using PAM-fluorometry, and photosynthesis rates using oxygen microelectrodes.

To assess the photosynthetic acclimation status of the coralline, we utilised the rapid light curve (RLC) function of the Diving-PAM. We based our approach on preliminary measurements made in November 2001 (Schwarz et al. 2003). The RLC function provides information about the photo-acclimated status of a plant given its recent light history. In a rapid light curve, $\Delta F / F_{\mathrm{m}}$ ' is measured following the application of a saturating pulse of light following each of eight $15 \mathrm{~s}$ periods of actinic light, provided by the Diving-PAM in ever increasing intensities from darkness. The RLC does not achieve steady state conditions during each light step
(Schreiber et al. 1986) and so does not necessarily mimic a traditional light curve; rather, it provides a snapshot of the current status of light adaptation to the ambient light conditions. Rather than photosynthesis per se, if irradiance, sample absorbance and the quantum yield are known, electron transport rate (ETR) can be calculated according to Genty et al. (1989). Alternatively, a relative electron transport rate (RETR) can be calculated, which does not account for the proportion of irradiance absorbed. In this study, RETR was calculated as $\Delta F / F_{\mathrm{m}}{ }^{\prime} \times$ PAR (Beer \& Axelsson 2004).

To obtain RLCs, the measuring fibre of the DivingPAM was clamped in a retort stand at a distance of $1 \mathrm{~cm}$ from the coralline surface. The actinic light of the PAM provides white light with a negligible amount of wavelengths beyond $700 \mathrm{~nm}$; however, a chief feature of ice is to absorb red light, i.e. >620 nm wavelengths. We modified the spectrum of the actinic light to better simulate the under-ice light environment by placing a blue tinted filter between the light source of the PAM and the coralline crust. The filter transmitted, on average, $95 \%$ of incident irradiance between 400 and $500 \mathrm{~nm}, 60 \%$ between 500 and $600 \mathrm{~nm}, 50 \%$ between 600 and 700 , and $98 \%$ at wavelengths $>700 \mathrm{~nm}$. Tests showed that there was still sufficient transmittance in the 600 to $700 \mathrm{~nm}$ band to enable the red LED to excite fluorescence, while the high transmission at wavelengths $>700 \mathrm{~nm}$ was essential to enable the PAM to still detect fluorescence. The irradiance supplied by the internal halogen lamp of the Diving-PAM, at each intensity of the RLC ( 0 to $25 \mu \mathrm{mol}$ photons $\mathrm{m}^{-2} \mathrm{~s}^{-1}$ ), was measured prior to the start of the experiment using a LiCor Li190SA quantum sensor attached to a LiCor Li1000 data logger. Intensities in the RLC supplied by the halogen lamp were unchanged when re-measured at the end of the experiment.

In the laboratory, RLCs were performed on freshly collected material that had been maintained at $-1^{\circ} \mathrm{C}$ in dim light (ca. $2 \mu \mathrm{mol}$ photons $\mathrm{m}^{-2} \mathrm{~s}^{-1}$ ) for the time between collection and measurements. After performing a RLC on freshly collected material in dim light (RLC1), we immediately illuminated the same material with $23.5 \mu \mathrm{mol} \mathrm{m} \mathrm{m}^{-2} \mathrm{~s}^{-1}$ of actinic light from the PAM (passed through the blue filter) to simulate sudden loss of ice cover. At the study location, average daily irradiance (average of 5 readings over a $24 \mathrm{~h}$ period) at a depth of $16 \mathrm{~m}$ has been measured at a maximum of $40 \mu \mathrm{mol}$ photons $\mathrm{m}^{-2} \mathrm{~s}^{-1}$ during ice-out. We selected $23.5 \mu \mathrm{mol}$ photons $\mathrm{m}^{-2} \mathrm{~s}^{-1}$ to represent the average daily irradiance immediately following ice-out (Schwarz et al. 2003). At 5 min intervals following the application of the $23.5 \mu \mathrm{mol}$ photons $\mathrm{m}^{-2} \mathrm{~s}^{-1}$ actinic light, a saturating pulse was applied at which time $\Delta F / F_{\mathrm{m}}{ }^{\prime}$ was measured and recorded. After $30 \mathrm{~min}$, a second RLC was performed (RLC2) and the process 
was repeated again over the next 30 min (RLC3). In total, 3 RLCs were performed on the same piece of material over a $1 \mathrm{~h}$ period. This procedure was repeated for 6 different areas of coralline crust from each of 15 and $20 \mathrm{~m}$. RETR was calculated as described above.

Photoacclimation to a higher light intensity usually involves an increase in rates of photosynthesis at saturating irradiance accompanied by an increase in the intensity at which the onset of light saturation occurs $\left(E_{\mathrm{k}}\right)$ (e.g. Boardman 1977). In contrast, photoinhibition is likely to be manifest as a decrease in photosynthetic capacity over time (e.g. Hanelt et al. 1997). Parameters expected to respond as a result of photoacclimation were calculated from each RLC by fitting a modification of the hyperbolic tangent relationship of Jassby \& Platt (1976) to RETR versus PAR data. Curve-fitting was undertaken using Sigmaplot (SPSS) using the equation: $\mathrm{RETR}=\mathrm{RETR}_{\max } \times \tanh \left(\mathrm{PAR} / E_{\mathrm{k}}\right)$, where $\mathrm{RETR}_{\text {max }}$ is light-saturated RETR, and $E_{\mathrm{k}}$ is the irradiance at the onset of saturation. A photoinhibition term was not included. Comparisons of derived parameters were made using a repeated measures MANOVA, with depth included as an independent variable, using Statistica for Windows 5.1 (Statsoft).

Oxygen electrodes: Rates of oxygen exchange under a range of irradiances were determined as the diffusive flux of oxygen across the boundary layer between the coralline-encrusted rocks and the surrounding water. Measurements were made on freshly collected material from depths of 15 and $20 \mathrm{~m}$. Rocks were placed in approximately $500 \mathrm{ml}$ of water in unstirred containers, in a darkened room. Water temperature was maintained at $0 \pm 1^{\circ} \mathrm{C}$. A Diamond General Development Corporation $737 \mathrm{GC}$ oxygen microelectrode, tip size approximately $150 \mu \mathrm{m}$, connected to a Diamond General 1231 Chemical Microsensor control box, was calibrated in air-saturated seawater at $-1^{\circ} \mathrm{C}$. The electrode was clamped in a micro-manipulator and the sensing tip lowered to approximately $1 \mathrm{~mm}$ above the surface of the coralline crust. The oxygen concentration was recorded once the electrode output had stabilised (usually within 5 to $10 \mathrm{~s}$ ). The electrode was then lowered in $0.05 \mathrm{~mm}$ increments, or less, and oxygen concentration measured at each point. Measurements continued until the electrode just touched the coralline surface. Oxygen profiles were conducted in the dark and at a range of increasing irradiances up to $40 \mu \mathrm{mol}$ photons $\mathrm{m}^{-2} \mathrm{~s}^{-1}$ on 2 replicates from depths of both 15 and $20 \mathrm{~m}$. Touching the surface of the coralline resulted in a slight movement which disturbed the boundary layer. As a consequence, between each irradiance intensity, the electrode was returned to $1 \mathrm{~mm}$ above the coralline crust and the boundary allowed to re-establish for $5 \mathrm{~min}$. Time con- straints prevented further replication. Irradiance was supplied by a halogen lamp with intensities that could be manually altered by means of a calibrated iris diaphragm, thereby preventing changes in light spectral quality with changing intensity. Light was passed to the sample through an optical fibre and the blue filter described for fluorescence measurements above to approximate the under-ice spectrum. Irradiance intensities at each setting were measured prior to starting oxygen profiles using a LiCor quantum sensor in place of an experimental rock.

Photosynthesis $(P)$ and respiration $(R)$ rates were calculated as the net diffusive oxygen flux $J(x)$, from the slope of the measured oxygen microprofiles within the diffusive boundary layer (DBL). Net diffusive oxygen flux ( $\mathrm{mmol} \mathrm{cm} \mathrm{cm}^{-2} \mathrm{~s}^{-1}$ ) was calculated using the formula: $J(x)=-\mathrm{D}_{\mathrm{O}} \delta \mathrm{C} / \delta(x)$ (Jørgensen \& Revsbech 1985), where $\mathrm{D}_{\mathrm{O}}$ is the molecular diffusion coefficient of oxygen (1.1 $\times 10^{-5} \mathrm{~cm}^{2} \mathrm{~s}^{-1}$ ) and $\delta \mathrm{C} / \delta(\mathrm{x})$ is the oxygen concentration gradient at distance $x\left(\mathrm{mmol} \mathrm{cm} \mathrm{cm}^{-3} \mathrm{~cm}^{-1}\right)$.

By plotting the net diffusive flux against irradiance for each profile, a net photosynthesis versus irradiance curve was constructed. The hyperbolic tangent relationship of Jassby \& Platt (1976) was fitted to the data as described above, but modified to include a respiration term where $\mathrm{p}=P_{\max } \times \tanh \left(\mathrm{PAR} / E_{\mathrm{k}}\right)+R$. The slope of the light limited portion of the curve, $\alpha$, was then calculated as $P_{\max } / E_{\mathrm{k}}$ and $E_{\mathrm{C}}$, the light compensation point for photosynthesis, as $R / \alpha$.

At the conclusion of the experiment, 3 pieces of coralline crust (approx. $1 \mathrm{~cm}^{2}$ ) were carefully chipped from rocks from the 2 depths. These were freeze-dried for subsequent analysis of chlorophyll a (chl a) and phycoerythrin (PE) content on return to New Zealand.

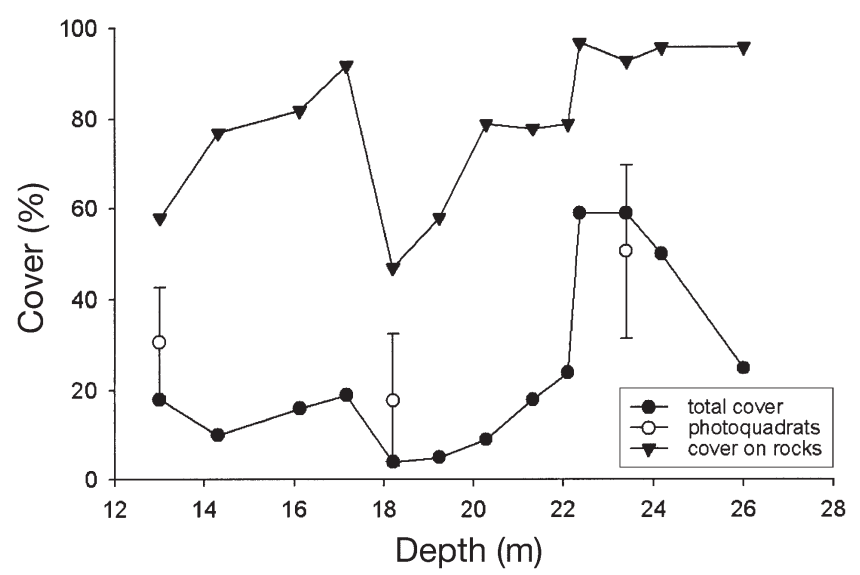

Fig. 1. The total 2-dimensional cover of crustose corallines and the proportion of rock substrate covered by corallines in $0.5 \times 0.5 \mathrm{~m}$ quadrats between depths of 13 and $26 \mathrm{~m}$. Cover (mean $\pm \mathrm{SD}$ ) estimated from eleven $0.25 \times 0.25 \mathrm{~m}$ photoquadrats on a parallel transect is also shown (O) 
The area of each sample was measured using the aluminium foil technique; sample surface was covered in foil, trimmed to fit, carefully removed and cut to allow flattening for calculation of the area using a simple image analysis programme. Samples for chl a extraction were then ground in $90 \%$ acetone in a motorized mortar and pestle before transfer to centrifuge tubes for overnight extraction $(\sim 12 \mathrm{~h})$ in the dark and at $4^{\circ} \mathrm{C}$. Samples were centrifuged for $10 \mathrm{~min}$ at $3000 \mathrm{rpm}$ and the supernatant read on a JASCO 7850 UV/VIS spectrophotometer at 750 and $665 \mathrm{~nm}$. Chl a concentrations were calculated according to Jeffrey \& Humphrey (1975). PE samples were ground in $0.01 \mathrm{M}$ Tris buffer, with $0.15 \mathrm{M} \mathrm{NaCl}$, adjusted to $\mathrm{pH}$ 7. Samples were centrifuged as above, and fluorescence of the extracts measured using a Perkin-Elmer fluorometer, with excitation and emission wavelengths of 495 and $572 \mathrm{~nm}$, respectively. A bulk sample of coralline material was used to prepare a local standard for conversion of fluorescence to absorption, and hence concentration. The bulk sample extract was prepared in the same way, and its absorption at $560 \mathrm{~nm}$ was determined. From this, PE was estimated using the equations of Glazer \& Hixon (1975). A dilution series of this extract was then used to calibrate the fluorescence technique.

\section{RESULTS}

\section{In situ characteristics}

In November 2003, the attenuation coefficient for downwelling irradiance $\left(K_{\mathrm{d}}\right)$ within the water column was $0.067 \mathrm{~m}^{-1}$ and, on average, between 29 October and 4 November, $0.48 \%$ of incident irradiance penetrated the ice cover. Irradiance at the sample depths (15 to $20 \mathrm{~m}$ ) was always less than $2 \mu \mathrm{mol}$ photons $\mathrm{m}^{-2}$ $\mathrm{s}^{-1}$ during measurements.

Along the length of the $50 \mathrm{~m}$ video transect, the substrate varied from coarse sand and gravel to rocks and large boulders. Throughout the depth range of the transect (13 to $26 \mathrm{~m}$ ), 4 to $60 \%$ of the seafloor or 47 to $97 \%$ of suitable rock substrate was colonised by conspicuous coralline crusts (Fig. 1). Total percent cover was highest at depths of 23 to $24 \mathrm{~m}$, due primarily to the abundance of suitable rock substrate at these depths.

In situ values of $\Delta F / F_{\mathrm{m}}{ }^{\prime}$ measured at each of 16,18 and $20 \mathrm{~m}$ covered a relatively narrow range from 0.613 to 0.698 (Fig. 2A) over the diel sampling periods. $\Delta F / F_{\mathrm{m}}{ }^{\prime}$ was higher at $16 \mathrm{~m}$ than at 18 and $20 \mathrm{~m}$, averaging $0.691(\mathrm{SD}=0.003), 0.639(\mathrm{SD}=0.005)$ and 0.632 $(\mathrm{SD}=0.007)$, respectively.

\section{Laboratory measurements}

In the laboratory, for RLC1, neither $E_{\mathrm{k}}$ nor RETR $\mathrm{Rax}_{\mathrm{max}}$ (Table 1) were significantly different between depths ( $t$-test, $\mathrm{p}=0.34$ and $\mathrm{p}=0.23$, respectively). For both depths, the shape of the RLCs (Fig. 3A,B) and consequently both $E_{\mathrm{k}}$ (Fig. 3C) and RETR $\mathrm{Rax}_{\text {max }}$ (Fig. 3D) changed over the course of an hour when the coralline algae were exposed to an irradiance intensity of $23.5 \mu \mathrm{mol}$ photons $\mathrm{m}^{-2} \mathrm{~s}^{-1}$. There was some evidence in the RLCs for photoinhibition at the highest irradiance for samples from $20 \mathrm{~m}$ (Fig. 3B). Nevertheless, as for 
Table 1. Mean and SE ( $\mathrm{n}=6$ ) of $E_{\mathrm{k}}$ and RETR (dimensionless) calculated from rapid light curves (RLCs) on shade-acclimated material (RLC1) using the Diving-PAM, and parameters calculated from individual $P$ versus $E$ curves obtained using oxygen electrodes for coralline crusts collected from 15 and $20 \mathrm{~m}$

\begin{tabular}{|c|c|c|c|}
\hline & & $15 \mathrm{~m}$ & $20 \mathrm{~m}$ \\
\hline \multirow[t]{2}{*}{ RLC1 parameters } & $\mathrm{RETR}_{\max }$ & $1.32(0.12)$ & $1.18(0.22)$ \\
\hline & $E_{\mathrm{k}}\left(\mu \mathrm{mol}\right.$ photons $\left.\mathrm{m}^{-2} \mathrm{~s}^{-1}\right)$ & $2.95(0.32)$ & $2.85(0.23)$ \\
\hline \multirow[t]{7}{*}{ Oxygen electrode parameters } & $P_{\max }\left(\right.$ net) $\left(\mathrm{mmol} \mathrm{O}_{2} \mathrm{~m}^{-2}\right.$ thallus $\left.\mathrm{d}^{-1}\right)$ & $\begin{array}{c}9.4 \\
13.4\end{array}$ & $\begin{array}{l}12.6 \\
19.9\end{array}$ \\
\hline & $E_{\mathrm{c}}\left(\mu \mathrm{mol}\right.$ photons $\left.\mathrm{m}^{-2} \mathrm{~s}^{-1}\right)$ & 0.04 & 0.05 \\
\hline & & 0.06 & 0.27 \\
\hline & $E_{\mathrm{k}}\left(\mu \mathrm{mol}\right.$ photons $\left.\mathrm{m}^{-2} \mathrm{~s}^{-1}\right)$ & $\begin{array}{l}2.51 \\
2.45\end{array}$ & $\begin{array}{l}5.53 \\
2.25\end{array}$ \\
\hline & $\alpha\left[\mathrm{mmol} \mathrm{O}_{2} \mathrm{~m}^{-2}\right.$ thallus $\left.\mathrm{d}^{-1}\left(\mu \mathrm{mol} \text { photons } \mathrm{m}^{-2} \mathrm{~s}^{-1}\right)^{-1}\right]$ & $\begin{array}{l}3.74 \\
5.48\end{array}$ & $\begin{array}{l}5.60 \\
3.59\end{array}$ \\
\hline & $R\left(\mathrm{mmol} \mathrm{O}_{2} \mathrm{~m}^{-2}\right.$ thallus $\left.\mathrm{d}^{-1}\right)$ & $\begin{array}{l}0.15 \\
0.35\end{array}$ & $\begin{array}{l}0.26 \\
0.96\end{array}$ \\
\hline & $P_{\max }\left(\right.$ net) $\left(\mathrm{mmol} \mathrm{O}_{2} \mathrm{mg} \mathrm{chl} \mathrm{a}^{-1} \mathrm{~d}^{-1}\right)$ & $\begin{array}{l}0.08 \\
0.11\end{array}$ & $\begin{array}{l}0.20 \\
0.32\end{array}$ \\
\hline
\end{tabular}
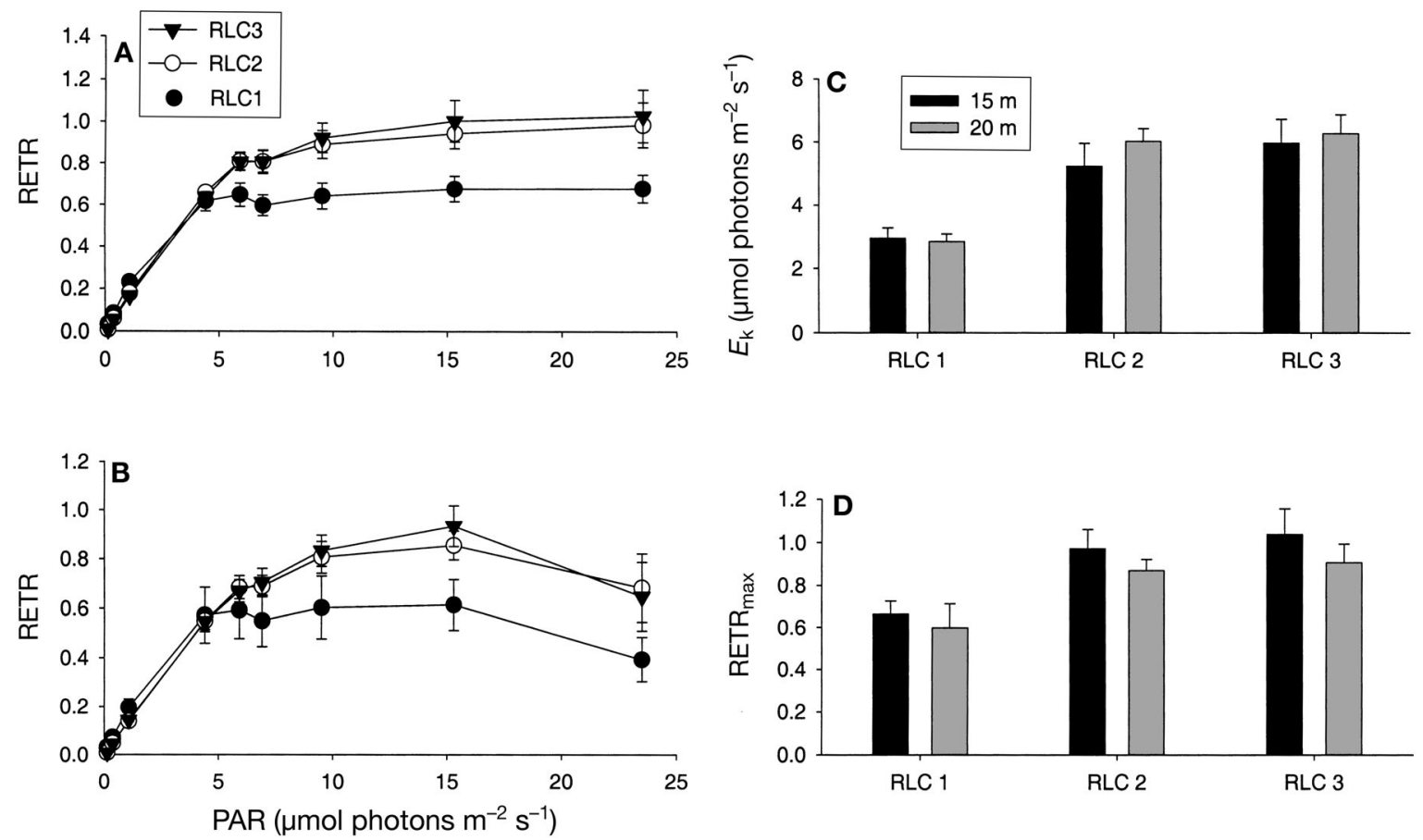

Fig. 3. Rapid light curves (RLC) for shade-acclimated $\left(0.2 \mu \mathrm{mol}\right.$ photons $\left.\mathrm{m}^{-2} \mathrm{~s}^{-1}\right)$ coralline algae (RLC1) and for algae subsequently exposed to an irradiance of $23.5 \mu \mathrm{mol}$ photons $\mathrm{m}^{-2} \mathrm{~s}^{-1}$ for 30 (RLC2) and $60 \mathrm{~min}$ (RLC3) from (A) $15 \mathrm{~m}$ and (B) $20 \mathrm{~m}$. Each curve is the mean \pm SE of 6 replicates. Parameters calculated from each curve are mean \pm SE for (C) $E_{\mathrm{k}}$ and (D) RETR $\mathrm{max}_{\mathrm{m}}$

$15 \mathrm{~m}$, the changes in $\mathrm{RETR}_{\max }$ and $E_{\mathrm{k}}$ were due to a slight but steady increase, largely over the first $30 \mathrm{~min}$, in $\Delta F / F_{\mathrm{m}}{ }^{\prime}$ under an irradiance of $23.5 \mu \mathrm{mol}$ photons $\mathrm{m}^{-2}$ $\mathrm{s}^{-1}$, suggesting that photoinhibition was minimal at this irradiance. After the first $30 \mathrm{~min}$ of exposure to an actinic intensity of $23.5 \mu \mathrm{mol}$ photons $\mathrm{m}^{-2} \mathrm{~s}^{-1}$, all replicates at both depths showed a significant increase in $E_{\mathrm{k}}$ and $\mathrm{RETR}_{\max }$ (MANOVA with repeated-measures, post hoc Tukey's test, p < 0.001) (Fig. 3C,D). There was no further significant change over the second $30 \mathrm{~min}$ period for either variable. There was no depth effect apparent in the calculated parameters. RETR max $_{\text {in- }}$ creased proportionally less than $E_{\mathrm{k}}$, meaning that an estimate of the photosynthetic efficiency $\left(\operatorname{RETR}_{\max } / E_{\mathrm{k}}\right)$ (analogous to $\alpha$ ) showed a significant $(\mathrm{p}<0.001$ ) decrease between RLC1 and RLC2. 


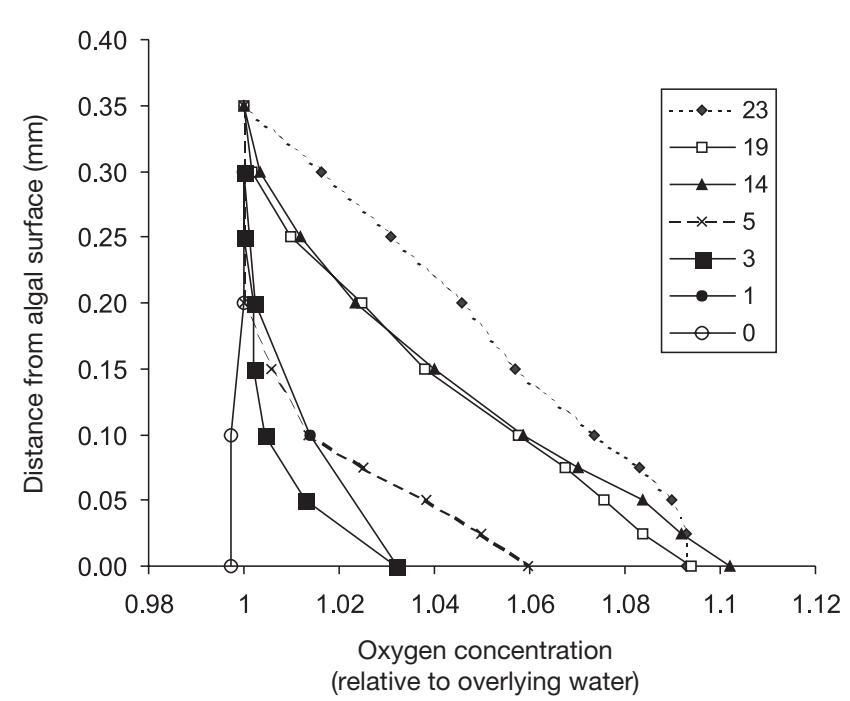

Fig. 4. Profile of changes in oxygen concentration within a $0.35 \mathrm{~mm}$ thick layer above the coralline crust under 7 irradiance intensities from dark to $23 \mu \mathrm{mol}$ photons $\mathrm{m}^{-2} \mathrm{~s}^{-1}$ for 1 replicate from $15 \mathrm{~m}$. Values for oxygen concentration are shown as relative to the oxygen concentration in the overlying water at $-1^{\circ} \mathrm{C}$

The oxygen microenvironment above the coralline surface showed changes relative to changes in the ambient irradiance (Fig. 4). In darkness, only slightly lower oxygen levels compared to the overlying water were found on the coralline surface, but at all subsequent light intensities, oxygen production by the corallines resulted in a supersaturated boundary layer of up to $0.35 \mathrm{~mm}$ thick. $E_{\mathrm{k}}$ calculated from the 4 resultant photosynthesis versus irradiance curves (Fig. 5) ranged from 2.25 to $5.53 \mu \mathrm{mol}$ photons $\mathrm{m}^{-2} \mathrm{~s}^{-1}$ (Table 1). $P_{\max }$ varied from 9.4 to $19.9 \mathrm{mmol} \mathrm{O}_{2} \mathrm{~m}^{-2}$ thallus $\mathrm{d}^{-1}$ at 15 and $20 \mathrm{~m}$, respectively (Table 1 ). Respiration rates were all $<1 \mathrm{mmol} \mathrm{O}_{2} \mathrm{~m}^{-2}$ thallus $\mathrm{d}^{-1}$ and $E_{\mathrm{C}}$ was $0.27 \mu \mathrm{mol}$ photons $\mathrm{m}^{-2} \mathrm{~s}^{-1}$ for 1 replicate from $20 \mathrm{~m}$ and $<0.1 \mu \mathrm{mol}$ photons $\mathrm{m}^{-2} \mathrm{~s}^{-1}$ for the remaining 3 replicates.

Chl $a$ and PE concentrations averaged 11.8 (SE = 3.4) and $18.9(\mathrm{SE}=5.3) \mu \mathrm{g} \mathrm{cm} \mathrm{cm}^{-2}$ (thallus), respectively at a depth of $15 \mathrm{~m}$, and $6.3(\mathrm{SE}=1.1)$ and $17.5(\mathrm{SE}=3.7) \mu \mathrm{g}$ $\mathrm{cm}^{-2}$ (thallus), respectively at a depth of $20 \mathrm{~m}$. There were no significant differences in PE or chl a concentrations between depths ( $t$-test, $\mathrm{p}>0.05)$. The ratio of $\mathrm{PE}$ to chl a was slightly higher at $20 \mathrm{~m}(2.9, \mathrm{SE}=0.74)$ than at $15 \mathrm{~m}(1.7, \mathrm{SE}=0.49)$ due to a lower chl a concentration at this depth.

\section{DISCUSSION}

Fluorescence and oxygen exchange experiments with coralline algal crusts at Cape Evans, collected from under ice, exhibited highly shade-adapted photo-

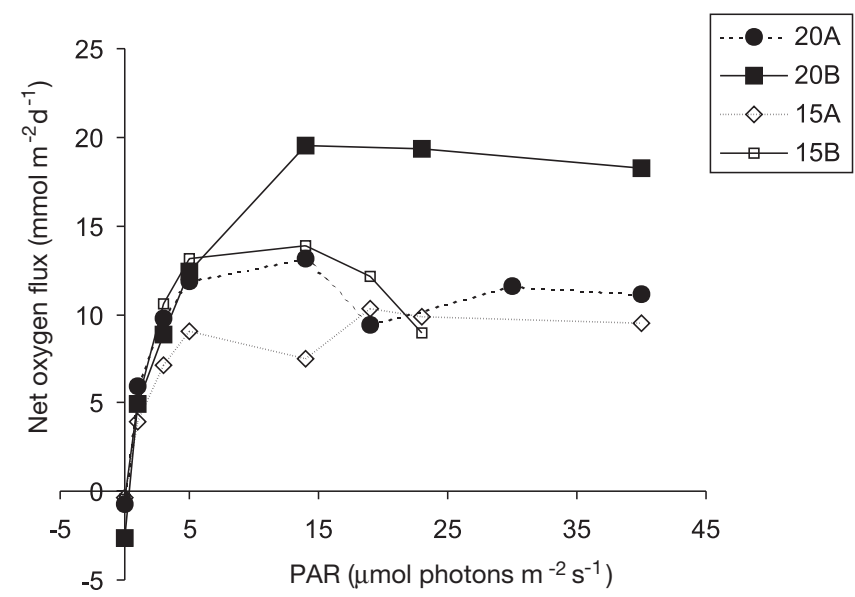

Fig. 5. Net diffusive oxygen flux (expressed as mmol oxygen $\mathrm{m}^{-2}$ thallus $\mathrm{d}^{-1}$ ) versus irradiance for coralline crusts on 2 rocks from a depth of $15 \mathrm{~m}$ and 2 rocks from a depth of $20 \mathrm{~m}$

synthetic characteristics, manifested as lower $E_{\mathrm{k}}$ and $P_{\max }$ than lower-latitude examples (Table 2). In this respect, they mirror the characteristics of Arctic encrusting corallines (Kühl et al. 2001).

There was some suggestion that the photosynthetic characteristics differed between samples from different depths. $\Delta F / F_{\mathrm{m}}{ }^{\prime}$ in situ was slightly higher at $16 \mathrm{~m}$ than at 18 and $20 \mathrm{~m}$. Algae from $20 \mathrm{~m}$ showed some evidence of photoinhibition when exposed to an irradiance of $23.5 \mu \mathrm{mol}$ photons $\mathrm{m}^{-2} \mathrm{~s}^{-1}$ under laboratory conditions and the PE:chl a ratio was higher at $20 \mathrm{~m}$ due to a lower chl a content rather than to an increase in PE concentration, a strategy interpreted by Glazer (1977) as adaptation to reduced light intensity. However, the absence of significant differences between depths in calculated photosynthetic parameters either from fluorescence or oxygen data, or in phycobilin concentration, suggested a generally similar degree of photoacclimation for plants from 15 and $20 \mathrm{~m}$. This probably reflects the similarity in light climate over this depth range for much of the year. It is possible that, rather than reflecting enhanced photoacclimation at greater depths, lower $\Delta F / F_{\mathrm{m}}{ }^{\prime}$, lower chl a concentration and photoinhibition at higher irradiances for plants from $20 \mathrm{~m}$ compared to those from 15 to $16 \mathrm{~m}$, suggest a reduced photosynthetic health at the time of sampling.

If these coralline communities approach the limits of a tolerable irradiance regime, it is likely that small differences in depth would translate to differences in physiological status when light stress is imposed over very long time periods. However, our data suggest that these organisms have a high capacity to tolerate prolonged low light stress ( $>1 \mathrm{yr}$ ). At the time of sampling, the study site had not been ice-free since March 2002, meaning that in situ irradiance had not exceeded 
Table 2. Photosynthetic parameters measured for selected non-geniculate (crustose) corallines over a range of latitudes. Values have been normalised to $\mathrm{mmol} \mathrm{O}_{2} \mathrm{~m}^{-2}$ thallus $\mathrm{d}^{-1}$ for comparison, units for $E_{\mathrm{k}}$ and $E_{\mathrm{c}}$ are $\mu \mathrm{mol}$ photons $\mathrm{m}^{-2} \mathrm{~s}^{-1}$. -: not reported

\begin{tabular}{|c|c|c|c|c|c|c|}
\hline Location & Taxon & Depth & $P_{\max }$ & $E_{\mathrm{c}}$ & $E_{\mathrm{k}}$ & Source \\
\hline $\begin{array}{l}\text { Young Sound, } \\
\text { Greenland, High Arctic }\end{array}$ & $\begin{array}{l}\text { Phymatolithon foecundum } \\
\text { and } P \text {. tenue }\end{array}$ & $17 \mathrm{~m}$ & $45.2-66.9$ & $0.71-1.82$ & $7.13-16.7$ & $\begin{array}{l}\text { Roberts et al. } \\
\text { (2002) }\end{array}$ \\
\hline Cape Evans, Antarctica & $\begin{array}{l}\text { Mesophyllum engelhartii or } \\
\text { Synarthrophyton patena }\end{array}$ & $15-20 \mathrm{~m}$ & $9.4-19.9$ & $0.04-0.27$ & $2.25-5.53$ & This study \\
\hline Århus, Denmark & Lithothamnion and Corallina & $0.5-1.5 \mathrm{~m}$ & 76.8 and 249.6 & - & - & Kaspar (1992) \\
\hline $\begin{array}{l}\text { Southern California, } \\
\text { USA }\end{array}$ & $\begin{array}{l}\text { Hydrolithon decipiens and } \\
\text { Pseudolithoderma nigra }\end{array}$ & Intertidal & 5.7 and 12.35 & - & - & $\begin{array}{l}\text { Littler \& Murray } \\
\text { (1974) }\end{array}$ \\
\hline $\begin{array}{l}\text { Lizard Island, Great } \\
\text { Barrier Reef }\end{array}$ & 4 non-geniculate taxa & $0-18 \mathrm{~m}$ & $15-132$ & - & $52-205$ & $\begin{array}{l}\text { Chisholm et al. } \\
\text { (1990) }\end{array}$ \\
\hline Waikiki Reef, Hawaii & 5 non-geniculate taxa & Fringing reef & $41.5-215.8$ & - & - & Littler (1973) \\
\hline $\begin{array}{l}\text { Tahiti Island, French } \\
\text { Polynesia }\end{array}$ & Hydrolithon onkodes & $0-1 \mathrm{~m}$ & $427.2-646.6$ & $7.34-13.9$ & $27-110.3$ & $\begin{array}{l}\text { Payri et al. } \\
\text { (2001) }\end{array}$ \\
\hline
\end{tabular}

$2 \mu \mathrm{mol}$ photons $\mathrm{m}^{-2} \mathrm{~s}^{-1}$ for $17 \mathrm{mo}$ at depths $>15 \mathrm{~m}$. Nevertheless, photosynthetic capacity remained high $\left(\Delta F / F_{\mathrm{m}}{ }^{\prime}=0.613\right.$ to 0.698$)$, toward the upper end of values measured in situ for a range of photosynthetic organisms under ice in a high-Arctic fjord (Kühl et al. 2001) and similar to measurements made on the same taxa at Cape Evans in 2001 (Schwarz et al. 2003).

Photosynthetic rates for corallines from both sample depths expressed per unit chl a ranged from 0.08 to $0.32 \mathrm{mmol} \mathrm{O}_{2} \mathrm{mg} \mathrm{chl} \mathrm{a}^{-1} \mathrm{~d}^{-1}$ (Table 1 ), which is only $6 \%$ of that for the foliose Phyllophora antarctica from the same site and depth range (average $2.94 \mathrm{mmol} \mathrm{O}_{2} \mathrm{mg}$ chl $a^{-1} \mathrm{~d}^{-1}$, calculated from data presented in Schwarz et al. 2003). Areal photosynthesis, corrected for percent cover in the case of corallines and biomass in the case of $P$. antarctica, is 2 orders of magnitude lower for corallines. Hence, areal production by these nongeniculate coralline algae is constrained not only by morphology, which sets a limit on photosynthetic area per unit substrate area, but also by lower rates of photosynthesis. Similar to the summary of Kühl et al. (2001) for high-Arctic primary producers, this results in a lesser contribution to overall benthic primary production under ice cover.

Average values of $E_{\mathrm{k}}$ were 3.2 and $2.9 \mu \mathrm{mol}$ photons $\mathrm{m}^{-2} \mathrm{~s}^{-1}$, calculated from the oxygen micro-electrode and PAM-fluorometry techniques, respectively. These values suggest an even greater degree of shade acclimation than corallines measured in a high-Arctic study (Roberts et al. 2002) where $E_{\mathrm{k}}$ ranged from 7.13 to $16.7 \mu \mathrm{mol}$ photons $\mathrm{m}^{-2} \mathrm{~s}^{-1}$ (Table 2) despite similar irradiance. Over our study, under-ice irradiance at depths of 16 to $20 \mathrm{~m}$ ranged from 0.07 to $1.75 \mu \mathrm{mol}$ photons $\mathrm{m}^{-2} \mathrm{~s}^{-1}$, equivalent to $<0.2 \%$ of incident irradiance. Consequently, PAR was always less than $E_{\mathrm{k}}$ and in situ photosynthesis will have been determined almost exclusively by changes in incident irradiance (Fig. 2B).
Irradiances at 16 to $20 \mathrm{~m}$ were marginally above $E_{\mathrm{c}}$ ( 0.04 to $0.27 \mu \mathrm{mol}$ photons $\left.\mathrm{m}^{-2} \mathrm{~s}^{-1}\right)$, and so even under $2.5 \mathrm{~m}$ of ice, plants at these depths were able to achieve net photosynthesis. $E_{\mathrm{k}}$ is, however, consistent with photosynthesis being optimal at light intensities close to the maximum ambient level at the time of sampling, but implies little ability to utilise higher irradiances that might occur under ice-free conditions unless the plants can adapt to increased irradiance should the ice cover be lost.

The corallines examined in this study appeared to have some capacity to accommodate higher irradiance. Not only was photosynthesis not greatly inhibited by irradiance, 1 to 2 orders of magnitude above ambient, but there was evidence of an increase in $E_{\mathrm{k}}$ and maximum electron-transport rate over a $1 \mathrm{~h}$ period. At irradiances up to $40 \mu \mathrm{mol}$ photons $\mathrm{m}^{-2} \mathrm{~s}^{-1}$, photosynthesis measured using oxygen micro-electrodes again showed no evidence of photoinhibition. While $40 \mu \mathrm{mol}$ photons $\mathrm{m}^{-2} \mathrm{~s}^{-1}$ represents the maximum recorded daily average irradiance during ice-out, the maximum instantaneous value measured in February 2002 at $15 \mathrm{~m}$ depth was $120 \mu \mathrm{mol}$ photons $\mathrm{m}^{-2} \mathrm{~s}^{-1}$ (Schwarz et al. 2003), an intensity shown to result in some photoinhibition for Phymatolithon foecundum in the Arctic (Roberts et al. 2002). Further experiments are required to investigate the response of coralline algae from different depths at high latitudes to short periods (days to weeks) of very high irradiance.

At a depth of $28 \mathrm{~m}$, where coralline cover was $>90 \%$ of the available suitable substrate, irradiance levels were calculated to be $0.07 \%$ of that incident on the surface of the ice. Such values are still higher than those estimated for the deepest records for coralline growth $(0.00005$ to $0.0009 \%$ of incident, Littler et al. 1991), and are marginally above the compensating irradiance measured in this study. However, the 
corallines at $28 \mathrm{~m}$ and deeper at Cape Evans will episodically experience higher irradiance when the sea ice breaks out during summer. Consequently, the summer window of net production for corallines is apparently longer than for Phyllophora antarctica, which showed an inability to maintain net photosynthesis under ice cover, but a good potential to utilise open-water conditions. Depending on ice conditions and the ability of the corallines to photoacclimate to higher irradiance, this, combined with the wider depth range that they occupy, suggests that their potential as a food source for benthic consumers (Norkko et al. 2004) may assume an importance that is disproportionate to their low photosynthetic rates.

The photosynthetic rates measured for the Cape Evans samples were slightly lower than the maximum rates of 45.2 to $66.9 \mathrm{mmol} \mathrm{O}_{2} \mathrm{~m}^{-2}$ thallus $\mathrm{d}^{-1}$ measured by Roberts et al. (2002) for Arctic corallines (Table 2). Nevertheless, the similarity in photosynthetic characteristics and average cover at equivalent study depths suggests that corallines in these 2 polar environments are able to achieve similar levels of production, depending to a great degree on the variability in the ambient light environment. The crustose coralline algae at Cape Evans do not appear to be as productive on an areal basis as the foliose Phyllophora antarctica, with which it co-occurs. However, the findings from this study fit our working hypothesis that the crustose corallines are able to extend beyond the depth range of foliose taxa through an ability to acclimate to very low intensities of PAR. The strategy of employing extremely shade-adapted characteristics enables corallines to persist with net carbon accrual under ice, while being able to tolerate periods of higher irradiance during ice-free conditions. This contrasts to the strategy of the co-occurring foliose taxon P. antarctica which is dependent on ice-free periods to achieve net production but is more efficient than the corallines at utilising high irradiance when it is available.

Acknowledgements. We are grateful for the assistance of the other members of the 2003, K081 dive team C. Marriot and O. Anderson, and D. Sutherland for pigment analyses. Antarctica New Zealand provided logistic support and this work was funded by FRST contract CO1X0220. We are grateful to W. Nelson (NIWA) and A. Harvey (La Trobe University, Melbourne) for discussion and information on the current taxonomic status of coralline algae in the Ross Sea. The manuscript was improved by comments from anonymous reviewers.

\section{LITERATURE CITED}

Alongi G, Cormaci M, Furnari G (2002) The Corallinaceae (Rhodophyta) from the Ross Sea (Antarctica): a taxonomic revision rejects all records except Phymatolithon foecundum. Phycologia 41:140-146
Beer S, Axelsson L (2004) Limitations in the use of PAM fluorometry for measuring photosynthetic rates of macroalgae at high irradiances. Eur J Phycol 39:1-7

Boardman NK (1977) Comparative photosynthesis of sun and shade plants. Annu Rev Plant Physiol 28:355-377

Chisholm JRM, Collingwood JC, Gill EF (1990) A novel in situ respirometer for investigating photosynthesis and calcification in crustose coralline algae. J Exp Mar Biol Ecol 141: $15-19$

Cormaci M, Furnari G, Scammacca B, Alongi G, Catra M (1998) Summer biomass of a population of Phyllophora antarctica (Phyllophoraceae, Rhodophyta) from Antarctica. Hydrobiologia 362:85-91

Dayton PK (1990) Polar benthos. In: Smith WE (ed) Polar oceanography. Part B. Chemistry, biology and geology. Academic Press, Boston, MA, p 631-685

Genty B, Briantais JM, Baker NR (1989) The relationship between the quantum yield of photosynthetic electron transport and quenching of chlorophyll fluorescence. Biochim Biophys Acta 990:87-92

Glazer AN (1977) Structure and molecular organization of the photosynthetic accessory pigments of cyanobacteria and red algae. Mol Cell Biochem 18:125-140

Glazer AN, Hixon CS (1975) Characterization of R-phycocyanin chromatophore content of R-phycocyanin and Cphycoerythrin. J Biol Chem 250:5487-95

Hanelt D, Melchersmann B, Wiencke C, Nultsch W (1997) Effects of high light stress on photosynthesis of polar macroalgae in relation to depth distribution. Mar Ecol Prog Ser 149:255-266

Jassby AD, Platt T (1976) Mathematical formulation of the relationship between photosynthesis and light for phytoplankton. Limnol Oceanogr 21:540-547

Jeffrey SW, Humphrey GF (1975) New spectrophotometric equations for determining chlorophylls $a_{1}, b_{1} c_{1}$ and $c_{2}$ in higher plants, algae and natural phytoplankton. Biochem Physiol Pflanz 167:191-194

Jørgensen BB, Revsbech NP (1985) Diffusive boundary layers and the oxygen uptake of sediments and detritus. Limnol Oceanogr 30:11-21

Kaspar HF (1992) Oxygen conditions on surfaces of coralline red algae. Mar Ecol Prog Ser 81:97-100

Kirk JTO (1994) Light and photosynthesis in aquatic ecosystems, 2nd edn. Cambridge University Press, Cambridge

Kirst GO, Wiencke C (1995) Ecophysiology of polar algae. J Phycol 31:181-199

Krause GH, Weis E (1991) Chlorophyll fluorescence and photosynthesis: the basics. Annu Rev Plant Physiol Plant Mol Biol 42:313-349

Kühl M, Glud RN, Borum J, Roberts R, Rysgaard S (2001) Photosynthetic performance of surface-associated algae below sea ice as measured with a pulse-amplitudemodulated (PAM) fluorometer and $\mathrm{O}_{2}$ microsensors. Mar Ecol Prog Ser 223:1-14

Littler MM (1973) The productivity of Hawaiian fringing-reef crustose Corallinaceae and an experimental evaluation of production methodology. Limnol Oceanogr 18:946-952

Littler MM, Murray SN (1974) The primary productivity of marine macrophytes from a rocky intertidal community. Mar Biol 27:131-135

Littler MM, Littler DS, Hanisak MD (1991) Deep-water rhodolith distribution productivity and growth history at sites of formation and subsequent degradation. J Exp Mar Biol Ecol 150:163-182

Miller KA, Pearse JS (1991) Ecological studies of seaweeds in McMurdo Sound Antarctica. Am Zool 31:35-48 
Norkko A, Thrush S, Cummings V, Funnell G, Schwarz A, Andrew N, Hawes I (2004) Ecological role of Phyllophora antarctica drift accumulations in coastal soft-sediment communities of McMurdo Sound, Antarctica. Polar Biol 27:482-494

Payri CE, Maritorena S, Bizeau C, Rodiére M (2001) Photoacclimation in the tropical coralline alga Hydrolithon onkodes (Rhodophyta Corallinaceae) from a French Polynesian reef. J Phycol 37:223-234

Roberts RD, Kühl M, Glud RN, Rysgaard S (2002) Primary production of crustose coralline red algae in a high Arctic Fjord. J Phycol 38:273-283

Schreiber U, Schliwa U, Bilger W (1986) Continuous recording of photochemical and non-photochemical chlorophyll fluorescence quenching with a new type of modulation fluorometer. Photosynth Res 10:51-62

Editorial responsibility: Otto Kinne (Editor-in-Chief), Oldendorf/Luhe, Germany
Schwarz A, Hawes I, Andrew N, Norkko A, Cummings V, Thrush S (2003) Macroalgal photosynthesis near the southern global limit for growth, Cape Evans, Ross Sea, Antarctica. Polar Biol 26:789-799

Steneck RS (1986) The ecology of coralline algal crusts: convergent patterns and adaptive strategies. Annu Rev Ecol Syst 17:273-303

Woelkerling WJ (1996) Subfamily Melobesioideae. In: Womerlsey HBS (ed) The marine benthic flora of southern Australia. Part IIIB. Gracilariales, Rhodymeniales, Corallinales and Bonnemaisoniales. Australian Biological Resources Study, Canberra, p 164-210

Zaneveld JS, Sanford RB (1980) Crustose corallinaceous algae (Rhodophyta) of the New Zealand and United States Scientific Expedition to the Ross Sea, Balleny Islands, and Macquarie Ridge, 1965. Blumea 26:205-231

Submitted: August 6, 2004; Accepted: January 13, 2005 Proofs received from author(s): May 18, 2005 